\title{
AN EVALUATION OF RAPID METHODS FOR ASSESSING THE ECOLOGICAL CONDITION OF WETLANDS
}

\author{
M. Siobhan Fennessy ${ }^{1}$, Amy D. Jacobs ${ }^{2}$, and Mary E. Kentula ${ }^{3}$ \\ ${ }^{1}$ Biology Department \\ Kenyon College \\ Gambier, Ohio, USA 43022 \\ ${ }^{2}$ Delaware Department of Natural Resources and Environmental Control \\ Water Resources Division/Watershed Assessment Section \\ Dover, Delaware, USA 19904 \\ ${ }^{3}$ U.S. Environmental Protection Agency \\ National Health and Environmental Effects Research Laboratory \\ Western Ecology Division \\ Corvallis, Oregon, USA 97333
}

\begin{abstract}
We analyzed 40 existing wetland rapid assessment methods that were developed for a variety of purposes, including informing regulatory decisions and local land use planning, and reviewed them for their potential to assess ecological integrity or condition. Four evaluation criteria were used. We determined if the method 1) can be used to measure condition, 2) is truly rapid, 3) includes a site visit, and 4) can be verified. This resulted in six methods being selected for evaluation relative to a conceptual model describing the core elements of a wetland assessment method, including universal indicators of soil, hydrology, and biotic communities, as well as regional indicators. An additional nine methods were kept for ideas on indicators, scoring, or regionalization. From this review, we identified five general areas that need to be addressed when adapting existing methods or developing new methods to assess condition: 1) definition of the assessment area, 2) treatment of wetland type, 3) approaches to scoring, 4) consideration of highly valued wetland types or features, and 5) procedures for validation with comprehensive ecological data. With scoring in particular, we present the advantages of a method that produces a single integrative score. Development of a rapid assessment method can assist those interested in incorporating condition assessment into their programs because they require less time in the field and less taxonomic expertise than more quantitative methods, which can lead to significant cost savings and increased sample sizes.
\end{abstract}

Key Words: ecosystem integrity, ecosystem stressors, indicators, wetland bioassessment

\section{INTRODUCTION}

Wetland ecosystems are under increasing pressure from human activities the world over (van Dam et al. 1998, Finlayson and Rea 1999, Brinson and Malvarez 2002, Junk 2002, Kentula et al. 2004). This has generated considerable interest in methods designed to assess the ecological condition or integrity of wetlands as a means to document the extent of degradation, to provide early warning of ecosystem stress or degradation, to determine the effectiveness of management actions, and to track wetland condition for regulatory programs charged with wetland management, restoration, and mitigation. Further reflecting the need for effective wetland monitoring methodologies, the National Water Quality Inventory Report to the U.S. Congress
(U.S. EPA 2002b) states that only $4 \%$ of U.S. wetlands have been monitored. This leaves insufficient data to evaluate the health of wetlands or to quantify the extent to which they are degraded.

The monitoring and assessment of wetland resources has been approached both through quantitative biological methods, such as indices of biotic integrity (Karr and Chu 1999) and hydrogeomorphic functional assessments (Brinson 1993, Smith et al. 1995), as well as through semiquantitative, rapid assessment methods (e.g., Mack 2001). Rapid methods require less time in the field and less taxonomic expertise than more quantitative methods, which can lead to significant cost savings and increased sample sizes. Therefore, rapid assessment methods are increasingly seen as central to 
implementation of wetland monitoring and assessment programs that, in turn, are recognized as essential to effective management of the resource (U.S. EPA 2003, Carletti et al. 2004).

The principle goals of wetland monitoring and assessment programs in the U.S. are to report on the ambient condition of wetland resources, evaluate restoration success, and report on the success of management activities. The "three-tier framework" is a strategy for designing effective monitoring programs. This approach breaks assessment procedures into a hierarchy of three levels that vary in the degree of effort and scale, ranging from broad, landscape assessments using readily available data (known as Level 1 methods), to rapid field methods (Level 2), to intensive biological and physicochemical measures (Level 3) (Brooks et al. 2004, Fennessy et al. 2004, Wardrop et al. 2007a, Whigham et al. 2007). Each level can be used to validate and inform the others; for example, intensive assessments (Level 3) are often used to calibrate or validate rapid methods (Level 2) (e.g., Mack et al. 2000, Wardrop et al. 2007a).

We set out to identify rapid methods most suitable for assessing the ecological condition of wetlands (defined following) as a first step in determining how best to employ Level 2 assessments within the threetier framework of a monitoring and assessment program. The assessment methods included in this analysis (Table 1) were developed for a variety of purposes, including use in regulatory decision making, local land use planning, and the evaluation of ambient ecosystem condition. This analysis will also help address calls to retire out-of-date methods and to strengthen and cross-calibrate those that are useful (Kusler and Niering 1998, Karr 1999, Innis et al. 2000). Our review is in no way meant to be a critique of each method for its intended use; rather, our goal was to evaluate each relative to its ability to ascertain ecological integrity or ambient condition. Despite the different program needs that sparked their development, many of these methods share common features. Throughout, we have highlighted the common ground, particularly the indicators or metrics that are used in multiple methods and in different parts of the country. These metrics are most likely to be transferable among states or regions and show promise for use outside of the U.S. (Carletti et al. 2004).

This review led us to recognize five common operational issues that are related to our criteria for evaluation (shown following). These must be addressed when developing a rapid assessment method to evaluate wetland condition. We discuss some of the advantages and disadvantages of how various methods address each issue. These issues are 1) how to define the assessment area when in the field; 2) how to incorporate different wetland types into the application of the method; 3) how scoring is handled; 4) whether or not certain wetland types or functions should be recognized for their value or the ecosystem services they provide, regardless of condition; and 5) the need for verification with comprehensive ecological data.

\section{EVALUATION OF RAPID METHODS}

\section{Study Approach}

We initially screened 40 methods, focusing on those reviewed by Bartoldus (1999) and others that were published or otherwise available through 2003. An initial assessment of each method was conducted; if it was obvious that the method was not at Level 2 of the three-tier system, it was eliminated from further consideration. For example, the original list included many Level 3 methods such as HGM functional assessments (per the approach described by Brinson 1993, Smith et al. 1995) and indices of biotic integrity (IBIs; see Karr and Chu 1999). Several landscape assessments (Level 1), such as the Synoptic Approach for Wetlands Cumulative Effects Assessment, which require detailed analysis using geographic information systems and no on-the-ground site assessment (Leibowitz et al. 1992, Abbruzzese and Leibowitz 1997), were also eliminated. After removal of these methods, 16 remained (Table 1).

We analyzed these methods in two steps. First, we established four criteria with which to evaluate each. The criteria were designed to identify methods that 1) measure ecological condition, 2) are truly rapid, 3) require a site visit, and 4) can be validated. Only the methods that met all four criteria were retained for a second, more detailed review. In the second step, the remaining methods were evaluated relative to a conceptual model describing the components of an ecologically sound wetland assessment method (Figure 1). All 16 methods were scrutinized for ideas on indicators, scoring, and regionalization.

\section{Criteria Used to Evaluate Assessment Methods}

In adopting or developing a rapid assessment method for use in ambient wetland monitoring and assessment programs, the following four criteria were deemed essential.

1) The method can be used to measure condition. A principal goal of the U.S. Clean Water Act is to maintain and restore the physical, chemical, and biological integrity of the waters of the United 


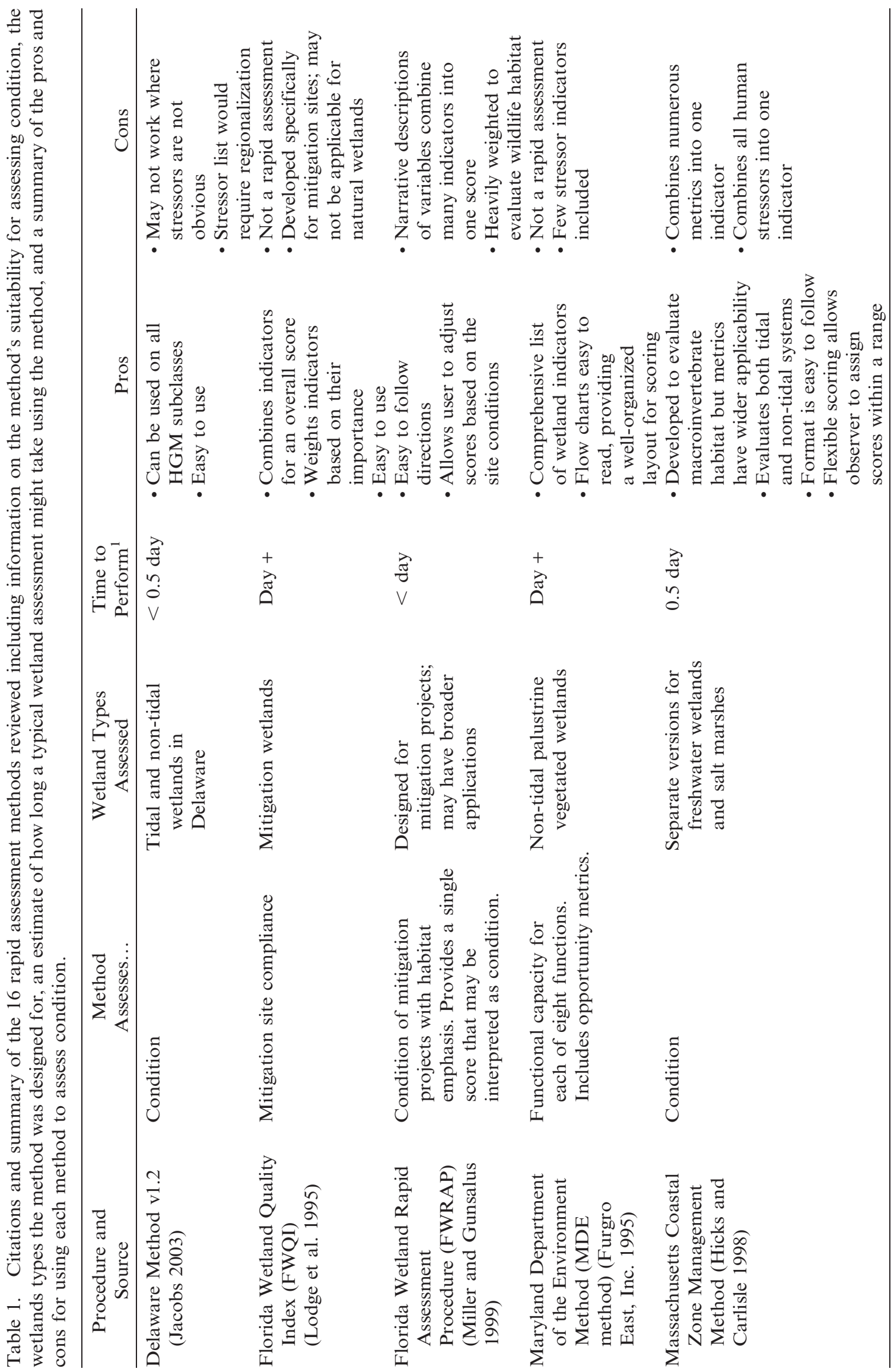




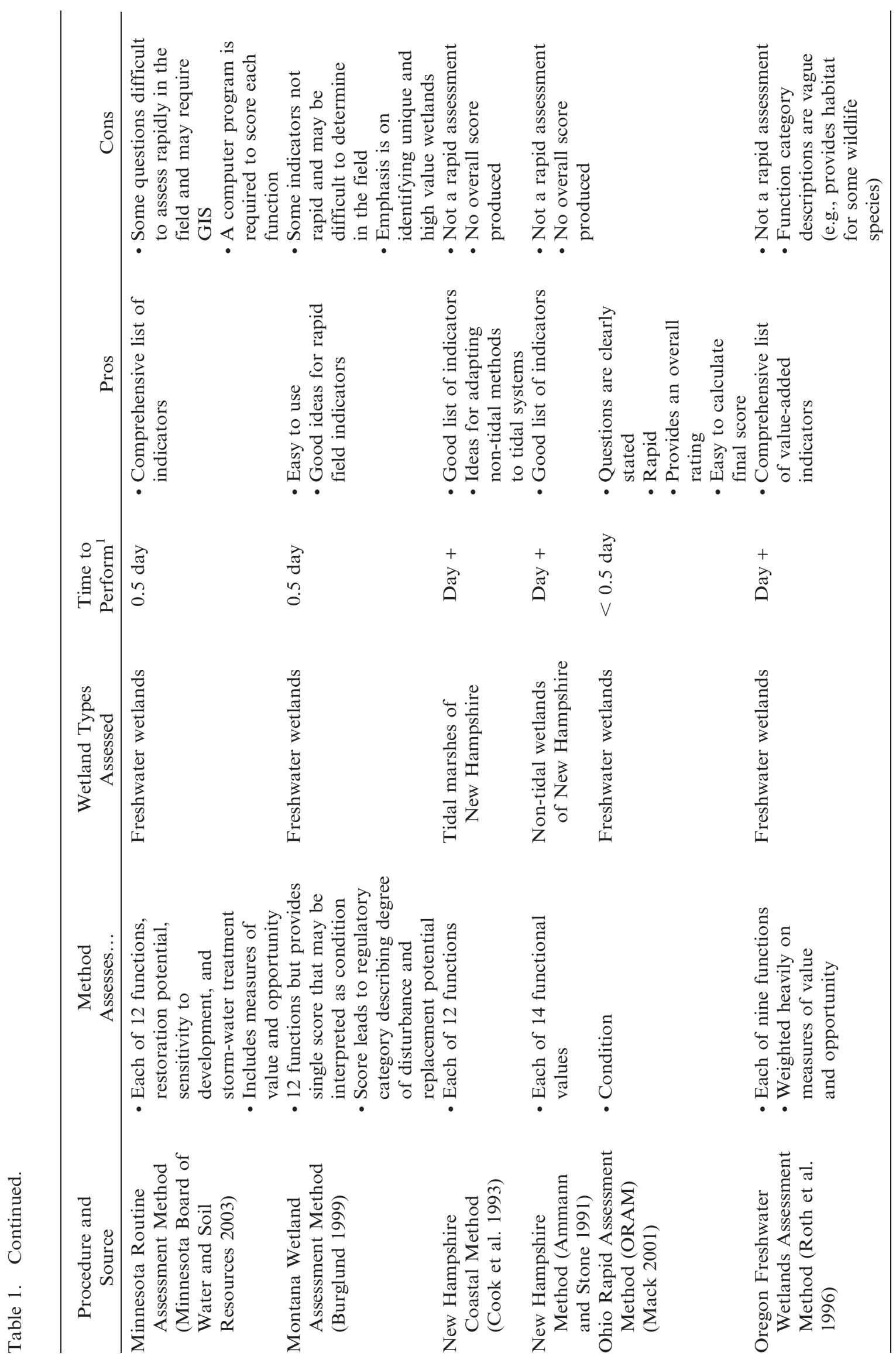




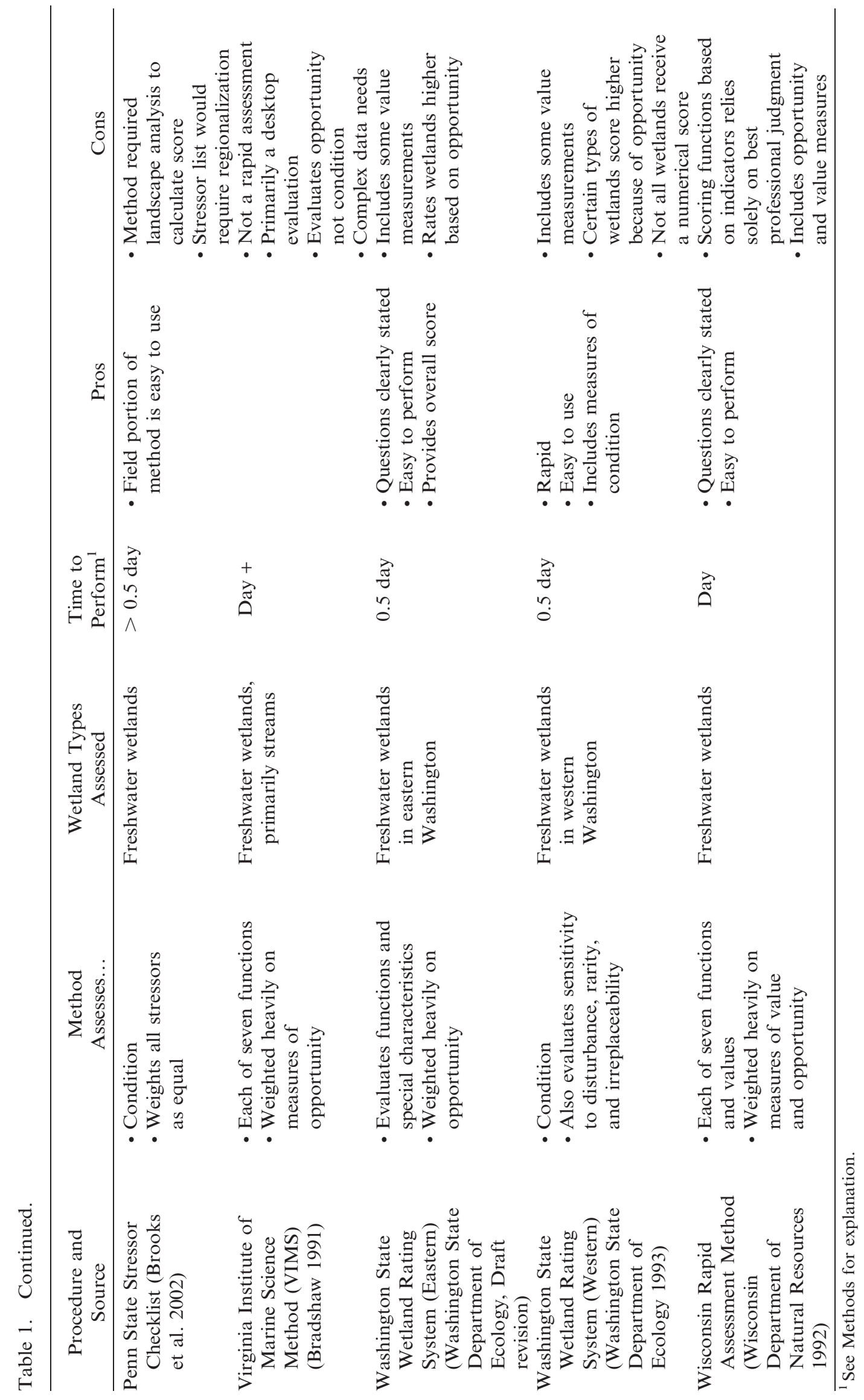




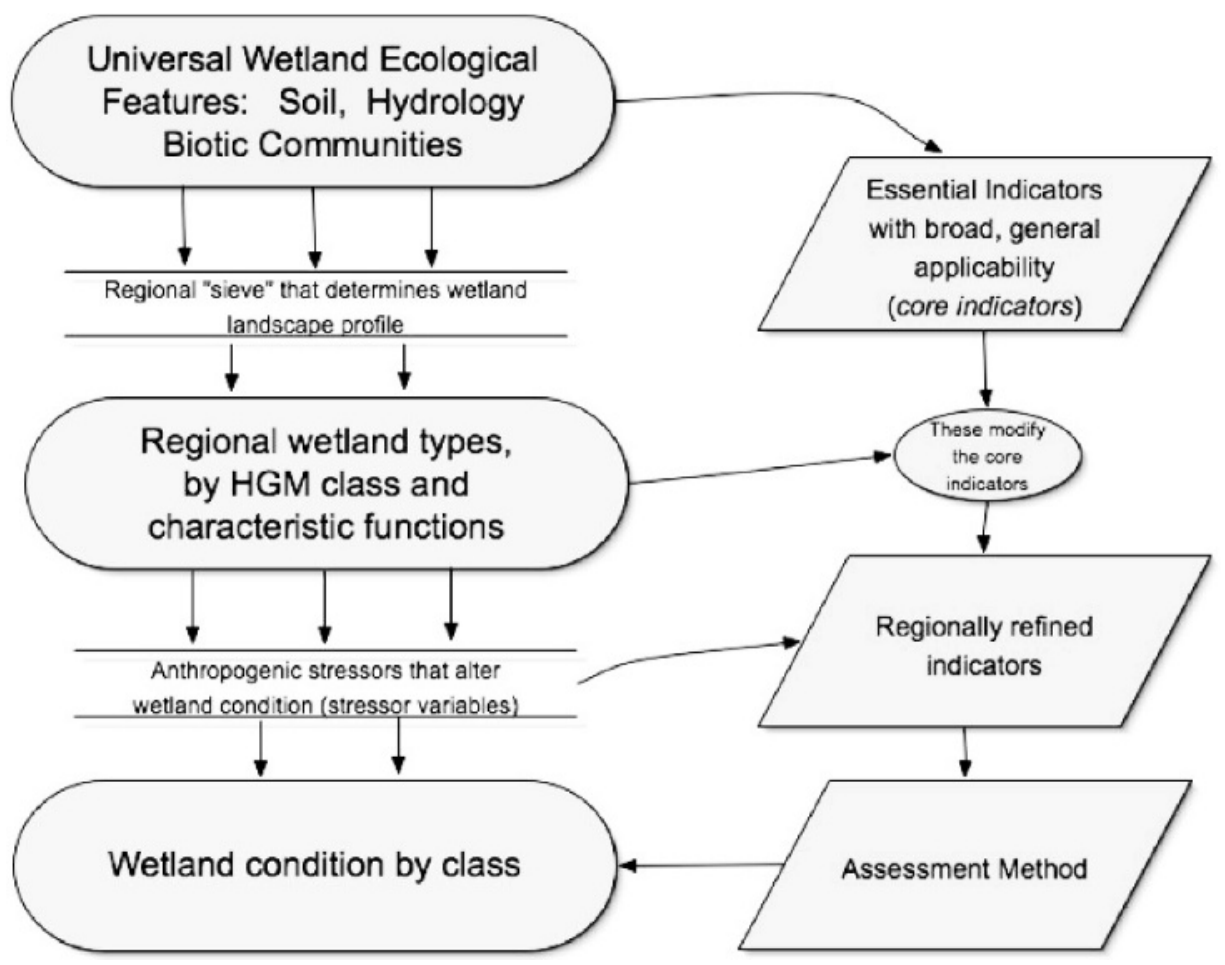

Figure 1. Conceptual model showing the links between the wetlands being evaluated and the core elements of a rapid assessment method. The model is hierarchical with respect to the ecological features that define wetlands (ovals on the left) and the indicators that can be adapted to evaluate the resulting wetland condition (boxes on right).

States. According to 33 U.S.C. §1251(a), integrity can be defined as the ability of a system to support and maintain a "...balanced integrated, adaptive community of organisms having a species composition, diversity, and functional organization comparable to the natural habitat of the region" (Karr and Dudley 1981, U.S. EPA 2002a). By contrast, ecological condition describes the extent to which a given site departs from full ecological integrity (if at all). Condition can be defined as the ability of a wetland to support and maintain its complexity and capacity for self-organization with respect to species composition, physico-chemical characteristics, and functional processes as compared to wetlands of a similar type without human alterations (sensu Karr and Dudley 1981). Ultimately, ecological condition results from the integration of the chemical, physical, and biological processes that maintain the system over time. Methods best suited to measure condition reflect this by providing a quantitative measure describing where a wetland lies on the continuum ranging from full ecological integrity (i.e., the least impacted or reference condition) to highly degraded (poor condition). A single numeric score is the result. This score is not meant to measure absolute value or have intrinsic meaning, but allows comparisons between wetlands to be made relative to reference condition.
Methods that evaluate condition and provide a single integrative score for each site effectively serve many monitoring needs because data on the ambient condition of the wetland resource provide an essential benchmark to determine the effectiveness of management actions. Relative to the requirements of the U.S. Clean Water Act, information derived from monitoring programs can also be used to develop and support aquatic life use designations for the implementation of wetland water quality standards. Because condition can describe the relative ability of a waterbody to support its designated uses, the adoption of a rapid method that assesses condition is a key in the implementation of such standards on a state-wide or national level. Assessing condition also alleviates the difficulty of quantifying multiple functions of wetlands at a single site and avoids the issues associated with combining multiple functions into a single score.

2) The method must be rapid. Consideration was given to the level of effort needed, as well as how much time a method would take to complete. A rapid method must be able to provide an accurate assessment of condition in a relatively short time period. For this reason, we defined "rapid" as taking no more than two people a half day total in 
the field and requiring no more than another half day of office preparation and data analysis to obtain a result. We estimated the time needed to use the methods through a combination of 1) personal experience with the methods, 2) input from others who had experience with the methods, and 3) best professional judgment based on the type of data required to complete a given method.

3) The method must be an on-site assessment. An accurate evaluation using a rapid method requires a site visit to ensure that the method captures the current condition of the wetland and does not infer condition based, for example, on characteristics of the surrounding landscape or on the potential of a wetland to perform certain functions.

4) The validity of the method can be determined. The validity of a Level 2 method can be determined using data gathered in empirical studies that employ more intensive wetland monitoring activities (i.e., Level 3 assessments). However, producing results that are comparable to those from an intensive method is not in itself sufficient in evaluating a rapid method. Clear and complete documentation of the assumptions behind the rapid method is essential to identify and fix problems, to calibrate the rapid method with the intensive method, and to interpret the results. Because there was little information on the extent of validation with intensive methods, we gauged a methods ability to be validated based on the use of metrics that could be supported by more intensive data, the process for calculating a final score, and the thoroughness of the documentation. The calculation of the final score was evaluated based on whether it was a clear and repeatable process for arriving at a final score. If the final score is assigned based on the best professional judgment of each user, then the validity of the method cannot be determined. We were conservative in making this determination in that we excluded methods only when final scores were arrived at using some form best professional judgment.

\section{Conceptual Model for Rapid Method Evaluation}

All methods that met the preceding four criteria were then evaluated relative to a conceptual model (Figure 1). The model illustrates components that are central to many rapid methods and defines categories of indicators that can be used in developing a method. The primary components of the model are the ecological attributes of wetlands (i.e., hydrology, soil, biota) and the regional hydrogeologic factors that determine wetland types (often described by HGM class). In the absence of anthropogenic stressors, these regional wetland types represent the reference condition. The model then accounts for the effects of anthropogenic stressors. Stressors are an important component of an assessment method because they act to degrade ecological condition. Knowledge of the stressors present in and around a wetland is also valuable in determining what measures are needed to improve condition. We evaluated if and how each of the methods addressed these components.

\section{RESULTS OF EVALUATION}

Analysis Relative to the Evaluation Criteria

Of the 16 methods evaluated (Table 1), only six met the four criteria we established: the Delaware Method, the Florida Wetland Rapid Assessment Procedure (FWRAP), the Massachusetts Coastal Zone Management Method, the Montana Method, the Ohio Rapid Assessment Method (ORAM), and the Washington State Wetland Rating System for Western Washington (Table 2). Of the 10 methods eliminated, six were dropped because we estimated that they would take a day or more to complete, in large part due to the complexities of the data required. For example, the Oregon Freshwater Wetlands Assessment Method (Oregon method) evaluates nine functions, each of which is assessed and assigned to a category (high, medium, low) of functional performance. Gathering the information needed for the indicators, such as "flashy water level response to storms" or "contribution to base flow," can be quite time-consuming. A lengthy list of indicators also increases the time required to gather information. For example, the Minnesota method provides an evaluation of 12 functions that, in turn, are calculated based on a list of 72 indicators (Table 1).

Most of the methods we eliminated gave no means to aggregate scores to reflect the integrated condition of the site. In addition, several of the eliminated methods had very limited documentation, with no clear means to reach a final score. Another common problem was that complex formulas or models were used to generate a final score, but no information was provided as to the reasoning behind such calculations.

\section{Analysis Relative to a Conceptual Model of Assessment}

In the second stage of the analysis, each of the six methods remaining were evaluated relative to the 
Table 2. A comparison of the six methods that may be used to assess condition relative to the conceptual model of wetland assessment summarizing how each method addresses the ecological features that define wetland ecosystems.

\begin{tabular}{|c|c|c|c|}
\hline Method & Hydrology & Soils & Biotic Communities \\
\hline Delaware Method v1.2 & $\begin{array}{l}\text { Incorporated into } \\
\text { method by evaluation } \\
\text { of stressors that affect } \\
\text { hydrologic processes }\end{array}$ & $\begin{array}{l}\text { Incorporated into portion } \\
\text { of the method evaluating } \\
\text { biogeochemical cycling and } \\
\text { the stressors that affect soil } \\
\text { processes }\end{array}$ & $\begin{array}{l}\text { Incorporated into the method } \\
\text { by the evaluation of stressors } \\
\text { that affect the biotic } \\
\text { communities }\end{array}$ \\
\hline $\begin{array}{l}\text { Florida Wetland Rapid } \\
\text { Assessment Procedure }\end{array}$ & $\begin{array}{l}\text { Considers evidence that } \\
\text { hydrologic regime is a } \\
\text { adequate to maintain a } \\
\text { viable wetland system }\end{array}$ & Not considered & $\begin{array}{l}\text { Considers wildlife utilization } \\
\text { in terms of habitat, } \\
\text { disturbance, food sources; } \\
\text { tree and shrub canopy in } \\
\text { terms of likelihood of } \\
\text { providing habitat; } \\
\text { herbaceous plants in terms } \\
\text { of cover, disturbance, native } \\
\text { vs. exotic }\end{array}$ \\
\hline $\begin{array}{l}\text { Massachusetts Coastal } \\
\text { Zone Management } \\
\text { Rapid Habitat } \\
\text { Assessment Method }\end{array}$ & $\begin{array}{l}\text { Evaluates in terms of } \\
\text { stressors and degree of } \\
\text { alteration, e.g., } \\
\text { restriction of inlets and } \\
\text { outlets }\end{array}$ & $\begin{array}{l}\text { Ranks by type with rocks } \\
\text { and gravel with little } \\
\text { organic matter rated the } \\
\text { lowest }\end{array}$ & $\begin{array}{l}\text { Considers number of } \\
\text { Cowardin vegetation classes } \\
\text { (more is better), number } \\
\text { and types of food sources, } \\
\text { presence of buffer }\end{array}$ \\
\hline $\begin{array}{l}\text { Montana Wetland } \\
\text { Assessment Method }\end{array}$ & $\begin{array}{l}\text { Considers duration of } \\
\text { surface water } \\
\text { Rates flood attenuation } \\
\text { as amount of site subject } \\
\text { to periodic } \\
\text { flooding } \\
\text { Rates surface water } \\
\text { storage as area of site } \\
\text { subject to periodic } \\
\text { flooding or } \\
\text { ponding relative to } \\
\text { frequency and } \\
\text { duration of flooding } \\
\text { Rates ground-water } \\
\text { discharge/recharge } \\
\text { based on presence of } \\
\text { indicators (e.g., } \\
\text { springs, seeps, inlet } \\
\text { but no outlet) }\end{array}$ & Not considered & $\begin{array}{l}\text { Rates structural diversity as } \\
\text { number of Cowardin } \\
\text { vegetation classes present and } \\
\text { relates to general wildlife } \\
\text { habitat } \\
\text { Considers habitat for federally } \\
\text { listed or proposed threatened } \\
\text { or endangered species } \\
\text { Considers fish/aquatic habitat } \\
\text { relative to duration and } \\
\text { frequency of flooding, cover } \\
\text { (e.g., rocks, logs), and shading } \\
\text { Rates food chain support } \\
\text { relative to vegetation cover } \\
\text { and structural diversity, and } \\
\text { hydrologic characteristics }\end{array}$ \\
\hline $\begin{array}{l}\text { Ohio Rapid Assessment } \\
\text { Method }\end{array}$ & $\begin{array}{l}\text { Considers source; } \\
\text { maximum water } \\
\text { depth, duration of } \\
\text { inundation (the more } \\
\text { permanent and deeper } \\
\text { the water the higher } \\
\text { the score); and } \\
\text { connectivity to other } \\
\text { surface waters and } \\
\text { upland }\end{array}$ & $\begin{array}{l}\text { Rates in terms of } \\
\text { disturbance }\end{array}$ & $\begin{array}{l}\text { Rates overall habitat } \\
\text { development and also degree } \\
\text { of alteration (see stressors) } \\
\text { Vegetation ranked as to: } \\
\text { number of communities } \\
\text { present, degree of } \\
\text { interspersion } \\
\text { Considers microtopography - } \\
\text { presence of hummocks, } \\
\text { woody debris, standing dead, } \\
\text { pools }\end{array}$ \\
\hline
\end{tabular}


Table 2. Continued.

\begin{tabular}{|c|c|c|c|}
\hline Method & Hydrology & Soils & Biotic Communities \\
\hline $\begin{array}{l}\text { Washington State } \\
\text { Wetland Rating } \\
\text { System, Western } \\
\text { Version }\end{array}$ & $\begin{array}{l}\text { Considers amount of } \\
\text { inundation and flow }\end{array}$ & $\begin{array}{l}\text { Gives extra points to } \\
\text { wetlands with a deep } \\
\text { organic layer }\end{array}$ & $\begin{array}{l}\text { Considers plants, mosses, } \\
\text { woody vegetation; } \\
\text { plant diversity; structural } \\
\text { diversity; degree } \\
\text { of interspersion; habitat } \\
\text { features (nests, snags, open } \\
\text { water), connection with a } \\
\text { stream; part of a corridor; } \\
\text { cover of vegetation types, } \\
\text { proximity to priority habitats }\end{array}$ \\
\hline
\end{tabular}

conceptual model (Figure 1) showing the relationship between the ecological features that define wetlands (ovals on the left), anthropogenic stressors that degrade sites, and the indicators used to evaluate the resulting wetland condition (boxes on right). The model illustrates how method development involves an understanding of 1) the ecological factors that create and sustain wetlands, 2) how regional hydrogeologic conditions such as geomorphology and the pathways of water flow drive the formation of regional wetland classes with characteristic structure and functions, and 3) how wetland types respond to anthropogenic disturbance (stressors). In other words, effective rapid assessment techniques are based on indicators of wetland condition derived from an understanding of the factors that create, maintain, and degrade wetlands on the landscape.

Wetlands, by definition, are characterized by three parameters: hydrology (e.g., hydroperiod, mean water depth), the presence of hydric soils, and the resulting biotic communities, particularly the presence of hydrophytic vegetation. Hydrology is considered the master variable of wetland ecosystems, driving the development of wetland soils and leading to the development of the biotic communities (Mitsch and Gosselink 2000). We term these the universal features of wetlands and were interested to see if and how each method addressed these fundamental ecosystem components (Table 2). Of the three parameters, we found that indicators based on soils are the least well developed and are entirely absent in some methods, such as the Florida and Montana methods. In contrast, all methods place considerable emphasis on hydrology indicators, both from the standpoint of characterizing hydrology (e.g., the duration of surface water in the Montana Method) to identifying hydrologic stressors (e.g., the degree of hydrologic alteration in the Massachusetts method, more detail on stressors follows). Indicators based on the structure of the biotic communities are perhaps the most extensive, with the bulk of these focused on vegetation community types (including the extent of invasive species) as a proxy for overall community diversity. Wildlife and amphibian habitat features are considered directly in five of the methods; only the Delaware Method that is made up solely of stressor indicators does not include wildlife indicators directly.

The conceptual model also recognizes that wetlands vary regionally and that this variability must be accounted for when developing reliable indicators of condition. Regionalization, in this case, is described in terms of the hydrogeologic settings and the hydrogeomorphology that dictate wetland form and function and that influence the selection or calibration of indicators (Table 3). Regionalization can also refer to the incorporation of values placed on specific wetland classes or ecosystem services that influence how a site is rated. Hydrogeologic settings are defined as the position of wetlands relative to surface- and ground-water flows, climate, and the characteristics of the surficial geology that control water movement (Winter 1988, 1992, 2001, Bedford 1996). The specific landscape settings that support development of various wetland types are termed "templates" by Bedford (1999). Templates are the result of physical variables operating at the landscape scale that generate and maintain different wetland types. The diversity of wetland types (kinds, numbers, relative abundance, and spatial distribution) can be summarized in a wetland landscape profile (e.g., Gwin et al. 1999). In this way, regional hydrogeologic and hydrogeomorphic characteristics act as a sieve, selecting for the wetland types and locations (i.e., the profile) that are sustainable in a particular landscape. Several of the methods shown in Table 3 categorize sites as either freshwater or saltwater (Washington and Massachusetts methods), while others employ the HGM classification (Brinson 1993). The Delaware Method includes 
Table 3. A comparison of the six methods relative to how each method addresses regional factors including the wetland types specific to the region as well as any consideration given to the ecosystem services provided by and/or special values placed on some wetlands.

\begin{tabular}{|c|c|c|}
\hline Method & Wetland Types & Services and Values \\
\hline Delaware Method v1.2 & $\begin{array}{l}\text { - HGM Classes; Regionalizes by } \\
\text { changing the thresholds for } \\
\text { interpretation of the assessment } \\
\text { relative to HGM class }\end{array}$ & - Not included \\
\hline $\begin{array}{l}\text { Florida Wetland Rapid } \\
\text { Assessment Procedure }\end{array}$ & $\begin{array}{l}\text { - Does not consider } \\
\text { wetland type in the assessment } \\
\text { - Designed for use in a wide } \\
\text { range of systems, but is not } \\
\text { intended to be used to } \\
\text { compare types }\end{array}$ & $\begin{array}{l}\text { - Primary focus of the assessment is habitat, also } \\
\text { considers water treatment }\end{array}$ \\
\hline $\begin{array}{l}\text { Massachusetts Coastal } \\
\text { Zone Management } \\
\text { Rapid Habitat } \\
\text { Assessment Method }\end{array}$ & $\begin{array}{l}\text { Has a form for all freshwater } \\
\text { wetlands and another for salt } \\
\text { marshes }\end{array}$ & - Not included \\
\hline $\begin{array}{l}\text { Montana Wetland } \\
\text { Assessment Method }\end{array}$ & $\begin{array}{l}\text { - Uses regional versions of } \\
\text { the national HGM } \\
\text { classes and vegetation } \\
\text { classes (aquatic bed, } \\
\text { emergent, scrub-shrub, } \\
\text { forested, moss-lichen) } \\
\text { - Rates relative abundance } \\
\text { of similarly classified } \\
\text { sites within the basin }\end{array}$ & $\begin{array}{l}\text { - Considers habitat for Montana Natural } \\
\text { Heritage Program listed species } \\
\text { - Flood attenuation - considers residences or } \\
\text { businesses downstream of wetland } \\
\text { - Sediment/nutrient/toxicant retention and } \\
\text { removal - opportunity (i.e., probable or } \\
\text { actual source); presence and amount of } \\
\text { vegetation, of flooding and ponding, and } \\
\text { of restriction of outlet } \\
\text { - Sediment/shoreline stabilization - cover } \\
\text { and flooding of plant species with deep, } \\
\text { binding roots } \\
\text { - Uniqueness - rareness of wetland type or } \\
\text { species present, and amount of disturbance } \\
\text { - Recreation or education - potential for use, } \\
\text { ownership, and amount of disturbance }\end{array}$ \\
\hline $\begin{array}{l}\text { Ohio Rapid } \\
\text { Assessment Method }\end{array}$ & $\begin{array}{l}\text { - Considers HGM class within } \\
\text { the assessment as a means } \\
\text { to compare like kinds of } \\
\text { sites and recognizes some } \\
\text { types as having special value }\end{array}$ & $\begin{array}{l}\text { - Gives extra points to wetlands of special } \\
\text { significance and wetlands that are habitat for } \\
\text { threatened or endangered species or are migratory } \\
\text { bird habitat }\end{array}$ \\
\hline $\begin{array}{l}\text { Washington State } \\
\text { Wetland Rating } \\
\text { System, Western } \\
\text { Version }\end{array}$ & $\begin{array}{l}\text { - Tidal and non-tidal evaluation } \\
\text { is not type specific }\end{array}$ & $\begin{array}{l}\text { - The office form of the assessment focuses on } \\
\text { determining the regulatory category of the } \\
\text { wetland based on whether it has been designated } \\
\text { by the state, heritage program, federal agency, } \\
\text { or local government as having sensitive or } \\
\text { endangered species, or is considered significant } \\
\text { locally for functions such as shoreline protection } \\
\text { and water storage. }\end{array}$ \\
\hline
\end{tabular}

a provision to place wetlands in the HGM classes a posteriori (i.e., following assessment), for the purposes of reporting or interpreting scores (i.e., ecological condition can be reported by HGM class). ORAM requires users to compare the wetland in question to high quality wetlands in the same HGM class to gauge its departure from the reference condition. Four methods recognize the value of specific wetland types or ecosystem services and award points to boost scores accordingly. For instance, the Montana, Ohio, and Washington methods all give extra points to sites that are known to support sensitive or endangered species.

Finally, wetlands are subject to human activities (e.g., changes in land use or hydrology) that stress the system and degrade its ecological integrity (Table 4). One of the assumptions underlying any condition assessment method is that wetlands re- 
Table 4. A comparison of the six methods relative to how each method addresses the stressors that act to degrade wetland condition.

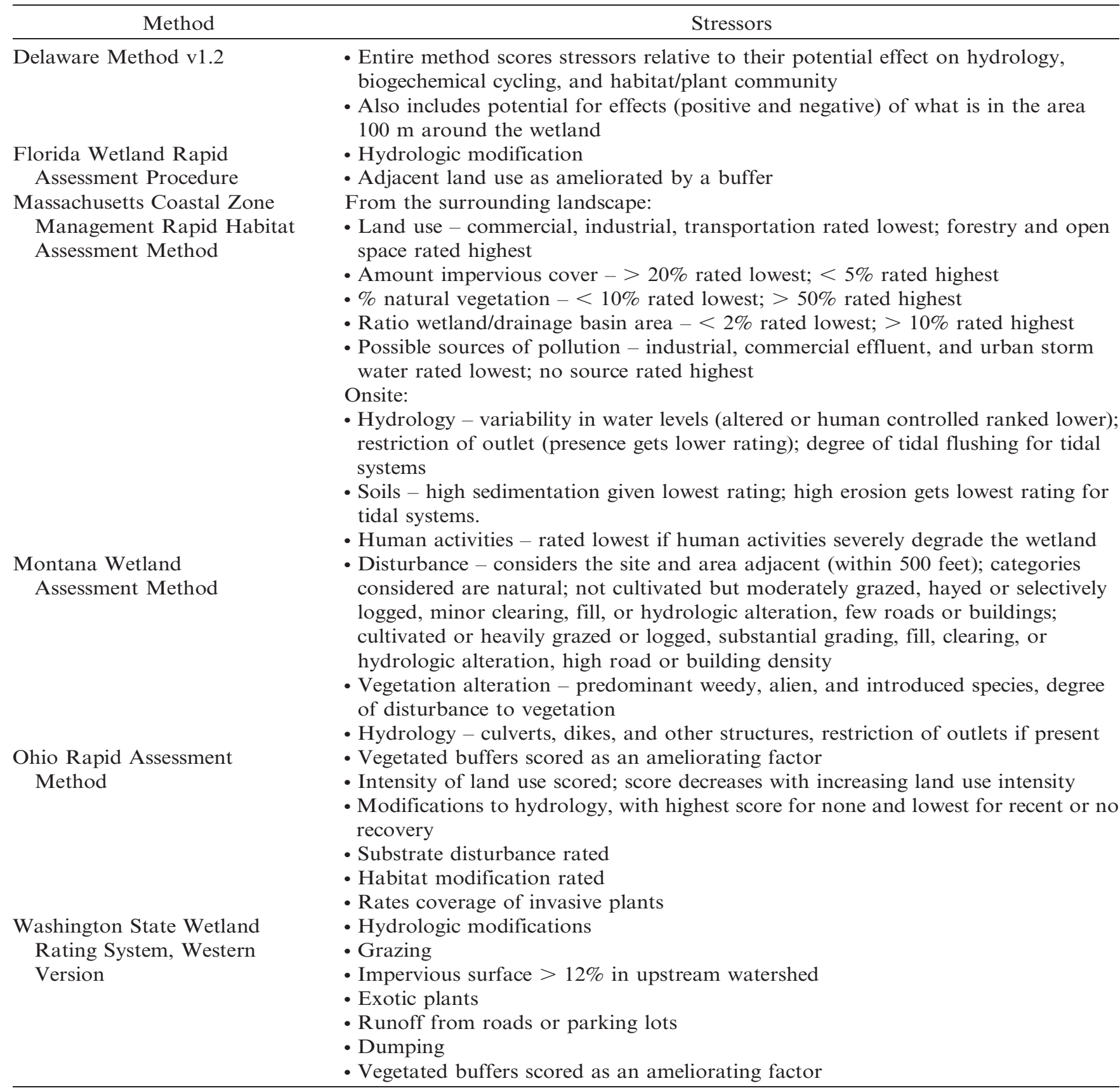

spond predictably to stressors. Indicators of wetland condition can be based either on the response of the wetland to these stressors (e.g., the percent cover of invasive species, the number of vegetation communities present) or on the stressors themselves (hydrologic modification). Stressor indicators can be very robust since the stressors have a negative effect on condition regardless of wetland type; for instance, hydrologic modification has a negative impact in a coastal marsh or a riparian forest. Some stressors can be used to refine methods regionally because the occurrence of stressors varies by region and wetland type. Methods range in their use of stressor indicators from those that only use stressor indicators (Delaware) to those that have very few stressor-based indicators (FWRAP). 
Table 5. Major categories of indicators used in the 16 rapid assessment methods reviewed, the characteristic(s) on which the indicator is based, and a tally of methods using that indicator (from high to low).

\begin{tabular}{|c|c|c|}
\hline Core Element & Indicators Developed for or Based on: & $\begin{array}{l}\text { Number of Methods Employing Indicator } \\
\text { (16 Maximum) }\end{array}$ \\
\hline \multirow[t]{11}{*}{ Hydrology: } & Hydrologic alterations (stressors) & 14 \\
\hline & Hydroperiod & 9 \\
\hline & Type of outlet restriction & 8 \\
\hline & Water quality & 8 \\
\hline & Surface water connectivity & 7 \\
\hline & Flood storage potential & 7 \\
\hline & Ground-water recharge and/or discharge & 4 \\
\hline & Water source(s) & 3 \\
\hline & Degree of water level fluctuation & 3 \\
\hline & Maximum water depth & 1 \\
\hline & Total & 64 \\
\hline \multirow[t]{8}{*}{ Soils/substrate: } & Soil type & 4 \\
\hline & Substrate disturbance & 2 \\
\hline & Presence of mottles & 1 \\
\hline & Depth of A horizon & 1 \\
\hline & Munsell color (matrix/mottles) & 1 \\
\hline & Microtopography & 1 \\
\hline & Sediment composition & 1 \\
\hline & Total & 11 \\
\hline \multirow[t]{11}{*}{ Vegetation: } & Number of vegetation classes & 12 \\
\hline & $\begin{array}{l}\text { Degree of interspersion (community types or } \\
\text { open water) }\end{array}$ & 8 \\
\hline & Extent of invasive species & 8 \\
\hline & Vegetation alterations & 6 \\
\hline & Habitat value to wildlife & 5 \\
\hline & $\begin{array}{l}\text { Endangered/threatened species, their habitat or } \\
\text { communities }\end{array}$ & 4 \\
\hline & Coarse woody debris & 3 \\
\hline & Dominant vegetation & 2 \\
\hline & Plant species diversity & 2 \\
\hline & Area of open water & 1 \\
\hline & Total & 51 \\
\hline \multirow[t]{10}{*}{ Landscape setting: } & Surrounding land use cover & 14 \\
\hline & Connectivity to other wetlands or corridors & 8 \\
\hline & Extent of and/or vegetation type in buffer & 7 \\
\hline & Extent of human land use in buffer & 5 \\
\hline & Wetland size & 5 \\
\hline & $\begin{array}{l}\text { Ratio of wetland to watershed size or watershed } \\
\text { size }\end{array}$ & 3 \\
\hline & Land use in watershed & 3 \\
\hline & Wetland morphology & 2 \\
\hline & Position of wetland in watershed & 1 \\
\hline & - & 48 \\
\hline
\end{tabular}

\section{Tally of Indicators}

We sorted the indicators used in the 16 methods into major categories to determine the extent to which they focus on the three parameters that define wetlands (hydrology, soils, biota) and on the landscape setting of the site (Table 5). All sixteen methods reviewed address hydrology; many emphasize the stressors that affect hydrologic processes (e.g., ditching and culverts; Table 5). Hydroperiod is another important consideration; half of the methods use the duration of flooding and the sources of water to the wetland. Soils received the least attention, with several methods not addressing soils at all. Features of the biotic communities, particularly vegetation, were the basis for many indicators. Most methods rely on the structural characteristics of the plant community (number of communities 
present, degree of interspersion, vegetation cover) as indicators of overall biotic richness. Plants are considered "one of the best indicators of the factors that shape wetlands within their landscape" (Bedford 1996). Wetland vegetation provides critical habitat structure for other taxonomic groups, such as epiphytic bacteria, phytoplankton, and some species of algae, periphyton, macroinvertebrates, amphibians, and fish; therefore, the composition and diversity of the plant community influences diversity in these taxonomic groups.

\section{OPERATIONAL CONSIDERATIONS AND CONCLUSIONS}

Our review of existing rapid assessment methods led us to identify issues that must be faced when adopting or developing such methods for wetland monitoring and assessment programs. These relate to operationalizing methods for use in the field: how the assessment area is defined, how wetlands of different types are handled by the method, how the method will be scored (e.g., will some indicators be weighted more heavily than others), how the values that we place on certain wetland functions or characteristics can be recognized, and how method verification can be approached.

\section{Definition of Assessment Area}

The requirement of a site visit to do the assessment implies that field protocols must be developed to ensure consistency and repeatability among users. One important decision in designing the protocol is how to define the area of wetland to be included in the assessment. This is referred to as the "wetland assessment area" or sometimes as the area within a "scoring boundary." In many instances, it is a simple matter of assessing the entire wetland. For example, when assessing a relatively small wetland the scoring boundaries will generally coincide with ecological or jurisdictional boundaries. When dealing with very large wetlands or a smaller area that is part of a larger wetland complex, decision rules to identify what area to include in the assessment must be clear. Misidentification of the assessment area can result in either the under- or overscoring of a given wetland (e.g., Mack 2001).

The definition of the wetland assessment area varies by method, ranging from sampling a fixed area around a point (for instance, a 0.5-ha area; the Delaware Method), to sampling the wetland as a whole (the New Hampshire Coastal Method). The latter approach can be problematic when large complexes made up of different wetland types are encountered, making it difficult to define a single wetland, or when very large wetlands require sampling. Some methods use a combination of approaches; for instance, the ORAM defines the assessment area using a "scoring boundary," which can be based either on the wetland's natural (jurisdictional) boundary (i.e., the whole site) or on boundaries defined by natural breaks in hydrology (much as stream sampling is done by a defined stream reach). This can mean that "whole" wetlands are not being sampled in the traditional sense, but the data collected will be consistent and provide an assessment of the ambient condition of the resource. The six methods that we applied to our model of assessment could all be easily adapted for use in whole wetlands or a defined assessment area within a wetland, depending on the user's objectives.

The definition of the assessment area is important because it influences how the data are collected and how the results are reported (e.g., by area of wetland resource, by wetland), understood, and, therefore used. An evaluation of what assessment area to use should consider 1) how well the definition can be applied in sample design and site selection (e.g., does it correlate with available mapped or GIS information), 2) how well and consistently the definition can be applied in the field (e.g., are boundaries easy to distinguish), 3) how ecologically meaningful the results will be, and 4) how useful the results will be in achieving the objectives of the monitoring or management program. A rationale can be made for using ecologically based units (i.e., wetlands, hydrogeomorphic units) as the assessment area, but this can make conducting the assessment and reporting the results problematic. For example, if the goal of the program is to assess the population of wetlands as a whole (in a watershed or region), then using a fixed area facilitates describing the characteristics of the population because drawing a sample from mapped data, locating the sample in the field, and reporting the results can easily be done in a manner that is consistent through all parts of the assessment (e.g., Wardrop et al. 2007a, Whigham et al. 2007). In our experience, it is difficult to establish a definition of a wetland site or related ecological unit that can be used to both draw a sample from mapped data and be consistently applied in the field. In addition, there is the problem of how to combine the data from wetlands of various sizes into a population estimate.

\section{Assessment of Different Wetland Types}

Recognition of different wetland types is an important consideration in the development and 


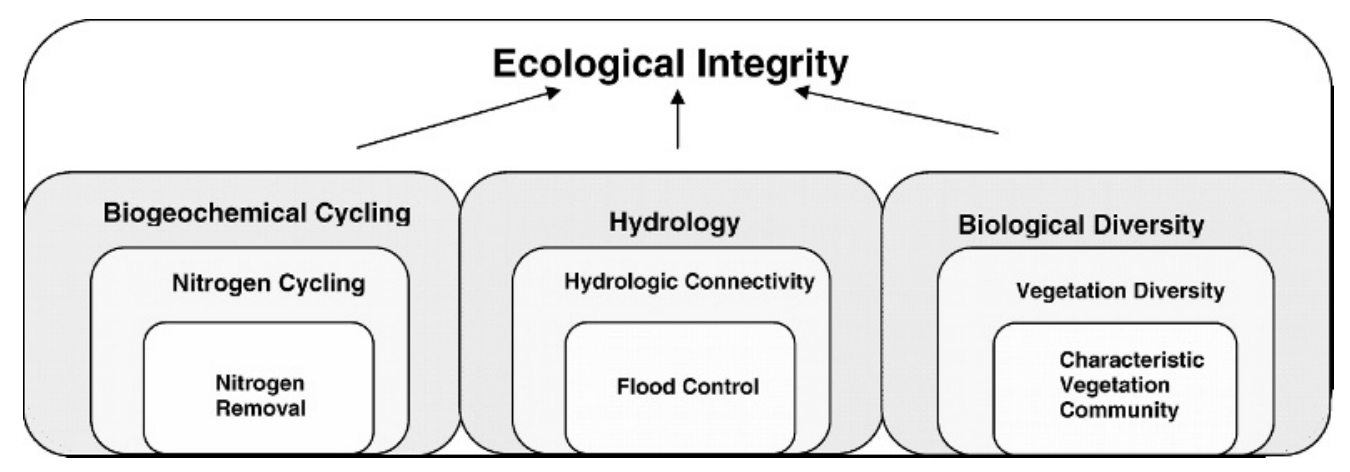

Figure 2. A schematic to illustrate the concept of ecological integrity as the integrating function of wetlands encompassing both ecosystem structure and processes. In this case, integrity is shown to include biogeochemical processes that lead to functions such as nitrogen removal, hydrologic processes that lead to the flood-control function, and habitat functions (based on Smith et al. 1995).

use of a rapid method because different classes of wetlands may be subject to different stressors and may vary in their relative susceptibility to particular stressors. The reference condition for a given class, defined by wetlands least impacted by human activities, is used to set the benchmark for the attainable ecological condition within a class.

Assessment of different wetland types can be accomplished in several ways: 1) develop a method for each class (e.g., HGM assessment), 2) weight the indicators according to wetland type within the method itself (e.g., ORAM) or in the calculation of the result (e.g., Delaware Method), or 3) have sets of indicators in the method that are used with particular wetland types (e.g., Washington State Wetland Rating System for Western Washington). The first approach allows for the use of type-specific field indictors, potentially increasing precision. This can be problematic, however, because each version will have to be validated separately and some wetlands, or some mosaics of wetlands, cannot be cleanly placed into a category.

The second and third approaches allow the creation of a single method for use in all wetland types and are, therefore, broadly applicable. Some methods using this approach embed the issues of class within the method itself; for instance, in the ORAM, the rater is asked to evaluate the wetland being assessed relative to other wetlands of similar type and hydrology (i.e., to other sites of the same HGM class). The result is that wetlands of different classes but with the same relative level of human impact should receive relatively similar scores (Mack et al. 2000).

The costs in time and resources needed to develop different versions of a method are important considerations. For instance, the sample size needed to detect differences (or lack thereof) between classes or other groupings statistically is influenced by the variability of the parameter(s) being measured. The U.S. Environmental Protection Agency's (U.S. EPA's) Environmental Monitoring and Assessment Program has arrived at a "rule of thumb" that, absent any information on the variability of what is being measured, 50 sites per class should be assessed during method development to increase the likelihood that the sample will be adequate. (See www.epa.gov/nheerl/arm/surdesignfaqs.htm for information on sample size and other monitoring design issues.) Therefore, a single method can be brought on line, evaluated, and developed more quickly than a suite of methods.

It is important to note that some methods are blind to wetland type (e.g., Delaware Method). The assumption behind such methods is that wetlands may differ in terms of their HGM class or floristic composition, but all are degraded by stressors. We have found that most of these methods track the type of wetland being assessed for uses such as ground-truthing wetland inventories, or for poststratification of the data for analysis and reporting (e.g., Wardrop et al. 2007a).

\section{Issues Associated with Scoring}

A major focus of our analysis was to identify those methods that could assess the ecological condition of a site and in doing so provide a single, integrative score. We took this approach for a variety of practical reasons (discussed following) that are supported by the ecological relationship between function and condition. Wetlands perform a wide variety of functions at a hierarchy of scales ranging from specific (e.g., nitrogen retention) to extensive (e.g., biogeochemical cycling) as a result of their specific physical, chemical, and biological attributes. 
At the highest level of this hierarchy is the maintenance of ecological integrity, the function that encompasses all ecosystem structure and processes (Figure 2) (Smith et al. 1995). If condition is excellent (i.e., equal to reference condition), then the ecological integrity of the wetland is intact and the functions typical of that wetland type should also occur at reference levels.

Many of the existing functional assessment methods provide information in terms of a separate "answer" for each function assessed (methods reviewed here include between eight and 14 functions), making them difficult to employ in ambient monitoring programs. Functional assessment results are presented either as a matrix of sites versus score by function or as a list of averages for each function. Either way results in a group of scores for each site that makes it difficult to compare their relative ecological status, the extent of anthropogenic impacts, or to make statements about the health of the resource as a whole. For example, the results of the Minnesota Routine Assessment Method (Version 1.0) and the Oregon Freshwater Wetlands Assessment Method are expressed as a series of ratings for each of nine functions. The Oregon method uses qualitative scores to indicate that the wetland "has the function" (earning a high score), that the "function is impacted or degraded" (mid), or that the "function is lost or not present" (low). The Minnesota Method assigns one of four ratings ranging from "exceptional" to "low" for each function. In a test of both methods to assess 10 depressional wetlands (Fennessy et al. 1998), approximately $40 \%$ of the functions evaluated by the Minnesota method scored "medium," while $65 \%$ of the functions received a score of "mid" using the Oregon method. It should be noted that the 10 wetlands included in that study (Fennessy et al. 1998) were selected to represent the full gradient of human disturbance (least impacted to highly impaired), so despite the large apparent differences in condition, all 10 wetlands received very similar scores, making it difficult to distinguish among them. This illustrates the problem in interpreting their results in ambient monitoring and assessment programs.

Another concern is that in some functional methods defining the highest level of a function does not necessarily equate with high ecological condition. Scoring by the highest degree of functionality can be a trap because maximizing one function (e.g., water quality improvement) may cause a reduction in others (e.g., supporting characteristic diversity) (Zedler 2005). Ultimately, if a wetland is functioning as an integrated system with a high degree of ecological integrity, it will perform all of its characteristic functions at the full levels typical of its class (i.e., at the level of the reference condition). If, in adopting a method, there is a desire to recognize wetlands that provide valuable functions despite moderate to high levels of degradation, points could be awarded to acknowledge this value after the score for condition has been determined.

A common approach used for scoring a rapid method is to assign scores by placing the "answers" to assessment questions into different categories and then assigning a score by category. For example, an assessment of the average buffer width around a wetland could be scored using categories such as "narrow" (e.g., 10-25 m), "medium" (25-75 m), or "wide" (greater than $75 \mathrm{~m}$ ). Different points would be awarded for each of the three categories. This approach tends to dampen the variability in scoring, resulting in less measurement error (i.e., different people are more likely to get the same answer making results repeatable and the method robust).

Several methods included in this review (e.g., New Hampshire method, Minnesota Routine Assessment Method) calculate the level of a function assigned to a wetland using simple equations that combine different variables. This makes the functional scores more difficult to validate (more variables, as well as their interactions, must be validated for each function). We also note that in arriving at a final score, several of the methods reviewed lead the person doing the assessment through a relatively detailed analysis requiring a lot of specific information, but then leave the ultimate result of the assessment to the "best professional judgment" of the user that appeared hard to defend (for example, the Wisconsin Rapid Assessment Method). We recommend a transparent and documented process for coming to a result for the assessment.

\section{Consideration of Highly Valued Wetlands or Features}

Some of the methods reviewed include what might be termed "value-added metrics." These are metrics that provide the opportunity for points to be added for a specific wetland type or feature that is deemed particularly valuable in the region, regardless of condition. For instance, wetlands in urban settings may have a high degree of human disturbance and therefore be of low condition, but they may be highly valued as green space or for the educational opportunities they provide. Metric 5 in the ORAM addresses regional values by adding points for wetland types that are rare and support a high level 
of plant diversity, such as the Oak Openings wetlands on the sand plains of Lake Erie. The Western Washington Method (from which ORAM was developed) does the same for eelgrass beds. Enhancing scores in this manner might be done for several reasons: 1) if the results of the rapid assessment are considered in regulatory decisions then more weight can be given to valued wetland types that are felt to be deserving of protection regardless of their condition; 2) some stakeholders who have a say in the development and use of such a method may feel more satisfied about its validity if scores are enhanced for wetlands or habitat features that they view as particularly important; or 3) addressing differences among wetland classes that other indicators are not capturing. If this approach is taken, it is important that such "value-added metrics" be kept separate from the metrics that indicate condition or stressors. By keeping condition metrics and value-added metrics separate, the metrics that reflect ecological condition can be combined for a condition score that can be used to track the status of the site or to report on the ambient condition of the resource, then the "valueadded metrics" can be factored in to get an overall score to be used in the regulatory process. This approach can substantially increase the flexibility of the method to meet program needs.

\section{Verification with Comprehensive Ecological Data}

A central component in the development of a rapid method is to determine its accuracy with more comprehensive ecological assessment data (Level 3 assessments such as IBI or HGM type data). The relationship between the rapid method and comprehensive data must be established so that the rapid method, with careful sampling design, can be used to extrapolate the more detailed results to the resource base as a whole (i.e., through probabilitybased sample design). It will also allow confidence limits on the use of a rapid assessment to be determined, increasing the reliability and defensibility of the method. The papers by Wardrop et al. $(2007 \mathrm{a}, \mathrm{b})$ on the assessment of the wetlands in the Upper Juniata watershed illustrate how the threetiered approach can be applied and how the results from each tier can be used to verify and inform the others. For example, the cumulative distribution functions for the wetland resource produced from the landscape, rapid, and intensive (HGM) assessments are very similar, indicating that all three methods generate comparable distributions of condition scores for the population. Further examination of the results using classification and regression tree (CART) analysis demonstrated that the landscape and rapid methods group sites along a condition gradient supported by Level 3 ecological data.

\section{SUMMARY}

This paper serves as a first step in providing guidance on how to develop a rapid assessment method or to adapt an existing method for use in wetland monitoring. From an initial review of 40 methods, 16 were selected for further analysis, and six were selected for an in-depth evaluation. We used four criteria to select these methods: 1) the method must measure the current condition of the wetland, 2) its use requires a site visit to complete the assessment, 3) the method is truly rapid, and 4) the assumptions that underlie the method can be verified. A necessary next step is to determine how these methods perform in the field through systematic field-testing across multiple regions. Several questions arise. Which indicators provide the most accurate and useful information across regions and among different wetland types? Should stressors be included in any method? Do the methods adequately characterize ecological condition? Are the results from such methods repeatable with different users? Answers to such questions are beyond the scope of this analysis and can only be reached through a rigorous field test of rapid assessment methods like those we have identified.

The wetland assessment methods reviewed have multiple uses, including ambient condition monitoring, mitigation planning and establishment of performance criteria, monitoring status and trends, local land-use planning to protect the ecological integrity of wetlands, and for use in regulatory decision making. These uses highlight the fact that a scientifically sound rapid assessment method can serve as a cornerstone for wetland protection programs.

\section{ACKNOWLEDGMENTS}

This review of wetland assessment methods was conducted in support of the U.S. EPA's Environmental Monitoring and Assessment Program. It has been subjected to review by the Natural Health and Environmental Effects Research Laboratory and Western Ecology Division and approved for publication. Approval does not signify that the contents reflect the views of the Agency, nor does mention of trade names or commercial products does not constitute endorsement or recommendation for use.

The authors thank several reviewers for their insightful comments that substantially improved the quality of this paper. John Calloway (University of 
San Francisco), Andree Breaux (California Regional Water Quality Control Board), David Lawhead (California Department of Fish and Game), Randy Apfelbeck (Montana Department of Environmental Quality), Brad Johnson (Colorado State University), and one anonymous reviewer all contributed valuable time in reviewing a previous draft. We give special thanks to Richard Sumner (U.S. EPA) for his invaluable assistance in developing these ideas and his endless energy in advancing the science that supports wetland protection.

\section{LITERATURE CITED}

Abbruzzese, B. and S. G. Leibowitz. 1997. A synoptic approach for assessing cumulative impacts to wetlands. Environmental Management 21:457-75

Ammann, A. P. and A. Lindley Stone. 1991. Method for the Comparative Evaluation of Nontidal Wetlands in New Hampshire. New Hampshire Department of Environmental Services, Concord, NH, USA. Source: NH Department of Environmental Services, Water Resource Division, Wetlands Bureau, P.O. Box 2008, Concord, NH 03302. NHDES-WRD-1991-3.

Bailey, R. G. 1995. Descriptions of the Ecoregions of the United States, second edition. U.S. Department of Agriculture, Forest Service, Washington, DC, USA.Miscellaneous Publication No. 1391.

Bartoldus, C. C. 1999. A comprehensive review of wetland assessment procedures: a guide for wetland practitioners. Environmental Concern, Inc., St. Michaels, MD, USA.

Bedford, B. L. 1996. The need to define hydrologic equivalence at the landscape scale for freshwater wetland mitigation. Ecological Applications 6:57-68.

Bedford, B. L. 1999. Cumulative effects on wetland landscapes: links to wetland restoration in the United States and Southern Canada. Wetlands 19:775-88.

Bradshaw, J. G. 1991. A Technique for the Functional Assessment of Nontidal Wetlands in the Coastal Plain of Virginia. Special Report No. 315. In Applied Marine Science and Ocean Engineering. Virginia Institute of Marine Science, College of William and Mary, Gloucester Point, VA, USA. Source: http://ccrm.vims.edu/VIMSMethodReportNo315.pdf.

Brinson, M. M. 1993. A Hydrogeomorphic Classification for Wetlands. Final Report to the U.S. Army Corps of Engineers, Waterways Experiment Station, Vicksburg, MS, USA.TechniTechnical Report WRP-DE-4.

Brinson, M. M. and A. Malvarez. 2002. Temperate freshwater wetlands: types, status and threats. Environmental Conservation 29:115-33.

Brooks, R. P., D. H. Wardrop, and J. A. Bishop. 2002. WatershedBased Protection for Wetlands in Pennsylvania: Levels 1 \& 2 Synoptic Maps and Rapid Field Assessments, Final Report. Penn State Cooperative Wetlands Center, University Park, PA, USA. Source: The Penn State Cooperative Wetlands Center, University Park, PA 16802. Report No. 2002-1.

Brooks, R. P., D. H. Wardrop, and J. A. Bishop. 2004. Assessing wetland condition on a watershed basis in the Mid-Atlantic Region using synoptic land-cover maps. Environmental Monitoring and Assessment 94:9-22.

Burglund, J. 1999. Montana Wetland Assessment Method.. Montana Department of Transportation and MorrisonMaierle, Inc., Helena, MT, USA. Source: Montana Department of Transportation, Environmental Services, 2701 Prospect Ave., P.O. Box 201001, Helena, MT 59620-1001.

Carletti, A., G. De Leo, and I. Ferrari. 2004. A critical review of representative wetland rapid assessment methods in North America. Aquatic Conservation: Marine and Freshwater Ecosystems 14:S103-S113.
Cook, R. A., A. J. Lindley Stone, and A. P. Ammann. 1993. Method for the Evaluation and Inventory of Vegetated Tidal Marshes in New Hampshire: Coastal Method.. Audubon Society of New Hampshire, Concord, NH, USA. Source: The Audubon Society of New Hampshire, 3 Silk Farm Road, Concord, NH 03301.

Cowardin, L. M., V. Carter, F. C. Golet, and E. T. LaRoe. 1979. Classification of Wetlands and Deepwater Habitats of the United States. U.S. Fish and Wildlife Service, Washington, DC, USA.FWS/OBS-79/31.

Fennessy, M. S., R. Geho, B. Elfritz, and R. Lopez. 1998. Testing the Floristic Quality Assessment Index as an Indicator of Riparian Wetland Disturbance. Ohio Environmental Protection Agency, Wetlands Unit, Division of Surface Water, Columbus, OH, USA.

Fennessy, M. S., A. D. Jacobs, and M. E. Kentula. 2004. Review of Rapid Methods for Assessing Wetland Condition. U.S. Environmental Protection Agency, Washington, DC, USA. EPA/600/R-04/009.

Finlayson, C. M. and N. Rea. 1999. Reasons for the loss and degradation of Australian Wetlands. Wetlands Ecology and Management 7:1-11

Furgro East Inc. 1995. A Method for the Assessment of Wetland Function.. Maryland Department of the Environment, Baltimore, MD, USA. Source: Fugro East Inc., Six Maple Street, Northborough, MA 01532

Hicks, A. L. and B. K. Carlisle. 1998. Rapid Habitat Assessment of Wetlands, Macro-Invertebrate Survey Version: Brief Description and Methodology. Massachusetts Coastal Zone Management Wetland Assessment Program, Amherst, MA, USA.Source: Bruce K. Carlisle, Massachusetts Coastal Zone Management, 100 Cambridge Street, Boston, MA 02202 .

Innis, S. A., R. J. Naiman, and S. R. Elliott. 2000. Indicators and assessment methods for measuring the ecological integrity of semi-aquatic terrestrial environments. Hydrobiologia 422: 111-31.

Jacobs, A. D. 2003. Delaware Rapid Assessment Procedure, Version 1.2. Delaware Department of Natural Resources and Environmental Control, Dover, DE, USA. Source: Delaware Dept. of Natural Resources and Environmental Control, Water Resources Division/Watershed Assessment Section, 820 Silver Lake Blvd., Suite 220, Dover, DE 19904.

Junk, W. J. 2002. Long-term environmental trends and the future of tropical wetlands. Environmental Conservation 29:414-35.

Karr, J. R. 1999. Defining and measuring river health. Freshwater Biology 41:221-34.

Karr, J. R. and E. W. Chu. 1999. Restoring Life in Running Waters: Better Biological Monitoring. Island Press, Washington, DC, USA.

Karr, J. R. and D. R. Dudley. 1981. Ecological perspective on water quality goals. Environmental Management 5:55-68.

Kentula, M. E., S. E. Gwin, and S. M. Pierson. 2004. Tracking changes in wetlands with urbanization: sixteen years of experience in Portland, Oregon, USA. Wetlands 24:734-43.

Kusler, J. and W. Niering. 1998. Wetland assessment: have we lost our way? National Wetlands Newsletter 20:1-14.

Leibowitz, S. G., B. Abbruzzese, P. R Adamus, L. E. Hughes, and J. T. Irish. 1992. A Synoptic Approach to Cumulative Impact Assessment: A Proposed Methodology. U.S. EPA, Environmental Research Laboratory, Corvallis, OR, USA. EPA/600/R-92/167.

Lodge, T. E., H. O. Hillestad, S. W. Carney, and R. B. Darling. 1995. Wetland Quality Index (WQI): A Method for Determining Compensatory Mitigation Requirements for Ecologically Impacted Wetlands. Proceedings of the American Society of Civil Engineers South Florida Section. Miami, FL, USA. Source: Law Engineering, 3301 Atlantic Ave., Raleigh, NC 27604

Mack, J. J., M. Micacchion, L. Augusta, and G. R. Sablak. 2000. Vegetation Indices of Biotic Integrity (VIBI) for Wetlands and Calibration of the Ohio Rapid Assessment Method for 
Wetlands v. 5.0. Final Report to U.S. EPA. Ohio Environmental Protection Agency, Division of Surface Water, 401 Wetland Ecology Unit, Columbus, OH, USA.

Mack, J. J. 2001. Ohio Rapid Assessment Method for Wetlands v. 5.0: User's Manual and Forms. Ohio Environmental Protection Agency Division of Surface Water, 401/Wetland Ecology Unit, Columbus, OH, USA.Technical Report WET/ 2001-1. Source: http://www.epa.state.oh.us/dsw/401/.

Miller, R. E. Jr. and B. E. Gunsalus. 1999. Wetland Rapid Assessment Procedure. Natural Resource Management Division, Regulation Department, South Florida Water Management District, West Palm Beach, FL, USA, Technical Publication REG-001. Source: http://www.sfwmd.gov/org/reg/ $\mathrm{nrm} /$ wrap99.htm.

Minnesota Board of Water and Soil Resources. 2003. Minnesota Routine Assessment Method for Evaluating Wetland Functions (MNRAM) Version 3.0. Minnesota Board of Water and Soil Resources, St. Paul, MN, USA, Source: http:// www.bwsr.state.mn.us/wetlands/mnram/index.html

Mitsch, W. J. and J. G. Gosselink. 2000. Wetlands, third edition. John Wiley \& Sons, Inc., New York, NY, USA.

Roth, E., R. Olsen, P. Snow, and R. Sumner. 1996. Oregon Freshwater Wetland Assessment Methodology. Wetlands Program, Oregon Division of State Lands, Salem, OR, USA, Source: Wetlands Program, Oregon Division of State Lands, 775 Summer St. NE, Salem, OR 97310.

Smith, R. D., A. Ammann, C. Bartoldus, and M. M. Brinson. 1995. An Approach for Assessing Wetland Functions Using Hydrogeomorphic Classification, Reference Wetlands, and Functional Indices. Waterways Experiment Station, U.S. Army Corps of Engineers, Vicksburg, MS, USA, Technical Report WRP-DE-9.

U.S. Environmental Protection Agency. 2002a. Biological Assessments and Criteria: Crucial Components of Water Quality Programs. U.S. Environmental Protection Agency, Washington DC, USA, EPA 822-F-02-006. (http://www.epa.gov/ost/ biocriteria/basics)

U.S. Environmental Protection Agency. 2002b. National Water Quality Inventory: 2000 Report. U.S. Environmental Protection Agency, Office of Water, Washington, DC, USA, EPA841-R-02-001.

U.S. Environmental Protection Agency. 2003. Elements of a State Water Monitoring and Assessment Program. U.S. Environmental Protection Agency, Washington DC, USA., EPA 841-B-03-003.
Van Dam, R. A., C. Camilleri, and C. M. Finlayson. 1998. The potential of rapid assessment techniques as early warning indicators of wetland degradation: a review. Environmental Toxicology and Water Quality 13:297-312.

Wardrop, D. H., M. E. Kentula, D. L. Stevens, Jr., S. F. Jensen, and R. P. Brooks. 2007a. Assessment of wetland condition: an example from the Upper Juniata Watershed in Pennsylvania, USA. Wetlands 27:416-31.

Wardrop, D. H., M. E. Kentula, S. F. Jensen, D. L. Stevens, Jr, and R. P. Brooks. 2007b. Assessment of wetlands in the Upper Juniata watershed in Pennsylvania, USA, using the hydrogeomorphic approach. Wetlands 27:432-45.

Washington State Department of Ecology. Draft revision. Washington State Wetlands Rating System: Eastern Washington. Second Edition. Washington State Department of Ecology, Olympia, WA, USA, Publication \#02-06-019. Source: http://www.ecy.wa.gov/biblio/0206019a.html.

Washington State Department of Ecology. 1993. Washington State Wetlands Rating System: Western Washington, second edition. Washington State Department of Ecology, Olympia, WA, USA, Publication \#93-74. Source: http://www.ecy.wa. gov/biblio/93074.html

Whigham, D. F., A. D. Jacobs, D. E. Weller, T. Jordan, E., M. E. Kentula, S. F. Jensen, and D. L. Stevens, Jr. 2007. Combining HGM and EMAP procedures to assess wetlands at the watershed scale - Status of flats and non-tidal riverine wetlands in the Nanticoke River watershed, Delaware and Maryland (USA). Wetlands 27:462-78.

Winter, T. C. 1988. Conceptual framework for assessment of cumulative impacts on the hydrology of non-tidal wetlands. Environmental Management 12:605-20.

Winter, T. C. 1992. A physiographic and climatic framework for hydrological studies of Wetlands. p. 127-48. In R. D. Robarts and M. L. Bothwell (eds.) Aquatic Ecosystems in Semi-arid Regions: Implications for Resource Management. N.H.R.I Symposium Series 7. Environment Canada, Saskatoon, Saskatchewan, Canada.

Winter, T. C. 2001. The concept of hydrologic landscapes. Journal of the American Water Resources Association $37: 335-49$.

Zedler, J. 2005. How compatible are biodiversity and ecosystem service goals? National Wetlands Newsletter 27:1.

Manuscript received 15 March 2006; accepted 12 March 2007. 